\title{
The Evaluation of Competency-Based Diagnosis System and Curriculum Improvement of Information Management
}

\author{
Dinesh Chandra Agrawal, Chaoyang University of Technology, Taiwan \\ Hsing-Yu Hou, National Taichung University of Science and Technology, Taiwan \\ Tao-Ming Cheng, Chaoyang University of Technology, Taiwan
}

\begin{abstract}
Teaching evaluation is an important issue in the learning process in higher education. In addition to the teaching evaluation on campus, feedback from alumni is also very important to instruction improvement. Undergraduates and graduates in universities are the main labor force in Taiwan; therefore, many higher education institutions pay attention to the feedback of competency. However, the written questionnaire has limitations and lacks sufficient evidence to improve curriculum planning and instruction activities. In the present study, a systematic survey in the 'University Career and Competency Assessment Network' was applied to analyze the results. Data were collected from 1,080 participants. The results can be summarized as follows: (1) 'Learn-Practice Fit' was positive to the 'Satisfaction' at workplaces. (2) 'Responsibility and discipline' were significantly positive concerning 'Communication and Expression,' 'Interpersonal Interaction', and 'Teamwork.' (3) 'Service' and 'Information technology writing' need to be improved in the training of Information Management students.
\end{abstract}

\section{KEYWORDS}

Alumni Satisfaction, Competency, Competency-Based Diagnosis, Curriculum Map, Information Management Education, Learn-Practice Fit, University Career and Competency Assessment Network

\section{INTRODUCTION}

In order to improve the learning process in higher education, most of the universities in Taiwan conduct teaching evaluation and alumni survey and then hopefully to form a competence-based diagnosis system to facilitate the process. Teaching evaluation is implemented by asking students to fill a questionnaire to give their feedback on the course to the instructor so that a revised pedagogy can be adopted in the next semester. Thus, teachers get the opportunity to know students' opinions to modify their teaching process (Johari et al., 2016; Harshman \& Yezierski, 2017; Xiong \& Niu 2018).

Besides teaching evaluation, feedback from recent graduates and alumni about their experience at workplaces is also very important (de St Jorre \& Oliver, 2018). Repeated alumni surveys facilitate

\section{DOI: 10.4018/IJICTE.2021040106}

This article, published as an Open Access article on December 4, 2020 in the gold Open Access journal, International Journal of Information and Communication Technology Education (converted to gold Open Access January 1, 2021), is distributed under the terms of the Creative Commons Attribution License (http://creativecommons.org/licenses/by/4.0/) which permits unrestricted use, distribution, and production in any medium, provided the author of the original work and original publication source are properly credited. 
in detecting students' emerging needs and problems and help management in introducing necessary changes in the curriculum (Lüer \& Aebi 2017; Kumm \& Laverentz, 2017; Ratri et al, 2019).

Several items in the alumni survey need the attention of management in higher education institutions for the improvement of students' competencies. A competency is a combination of attitude, behavior, knowledge, and skill that contribute to an individual's needs and success (Boury et al., 2013; Mah, 2017; McCall, 1998). Many reports have shown that competency-based teaching and learning can improve the quality of curriculum and education (Gunawardena, 2014; Montoya, 2013; Rizalyn \& Shuichi, 2003; Steel, 2018). In order to examine the authentic and self-steering study programs, competency-based diagnosis is increasingly being used for designing a course and teaching method, especially in vocational education (CAHME, 2015; Wesselink et al., 2010). Also, the evaluation of students' competencies at workplaces is important to ascertain that graduating students have developed necessary professional competencies to carry out the tasks at their workplaces (Bossers et al., 2002, 2007; Miller et al., 2001).

However, the general teaching evaluation and competency diagnosis are independent of each other. Due to this, there is insufficient evidence to improve curriculum planning and instruction activities. Also, concerning the competency evaluation, the number of samples and the written reflections are limited and inefficient (Davies et al., 2013; Elliott, 2017; Irvine et al, 2008). This creates room for more research, and through a cross-domain information system, the survey results can be more efficient and more complete. This is the first objective of the study. Several researchers reported that the planning and application of evaluation systems by students at the campus, and alumni after graduation is important (Elstad et al., 2015; Iezzi, 2005; Liu et al., 2016; Onwuegbuzie et al., 2007; Xu, 2012). Therefore, systematic competency diagnosis and teaching evaluation are necessary.

Keeping this need in mind, since 2014, the Ministry of Education (MOE), Taiwan had set up an alumni tracking mechanism for university graduates on career paths, career situations, their needs, and perceived gaps between their training and current work, competency acquisition, etc. The data is collected from students' one-year after their graduation. Students provide feedback to universities in order to improve students' career training and curriculums. With this objective, each year, the case university carries out alumni surveys to collect alumni' work feedback and then shares it with concerned departments to let them evaluate curriculum maps.

In addition to the alumni survey, the MOE has set up a University Career and Competency Assessment Network (UCAN) system to evaluate the effect of competency training before the students join their jobs. The goal of UCAN is to help students understand the direction of their career development and strengthen their competency. Through career interest exploration and competency diagnosis, students can increase their understanding of a workplace, plan self-cultivation goals, realize competency gaps, and improve their competitiveness. Therefore, the second objective of the study is to link the UCAN and graduate flow surveys to disclose the competency gaps through the analysis reports.

As shown in the research framework (Figure 1), career interest surveys, competency development, and teaching feedback, and graduates flow surveys are linked to professional competency and teaching evaluation in the UCAN system which is further linked to curriculum maps to do further competencydiagnosis analysis. In nutshell, the objectives of this study are: (1) to evaluate the relationship between the results of competency evaluation and alumni feedback using the UCAN report system, (2) to find competency gaps in the alumni feedback, and, (3) to check the curriculum map of the academic institution and suggest ways to teachers for improvement in their instructional activities. This research may be useful for universities and policymakers in improving students' competencies and career development. 


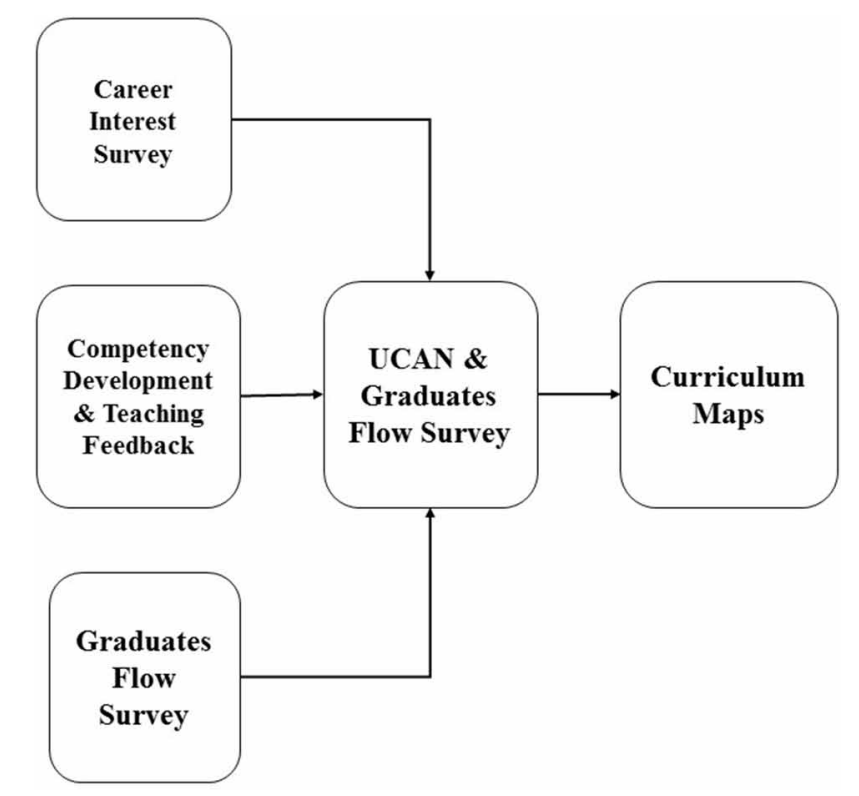

\section{LITERATURE REVIEW}

\section{University Career and Competency Assessment Network (UCAN) System and UCAN Report System}

In Taiwan, the 'University Career and Competency Assessment Network' (UCAN) system set by the Ministry of Education can support the career clusters' interest survey according to States' Career Clusters Initiative (2005). Besides, there are eight items in common competencies including 'Communication and expression,' 'Continuous learning,' 'Interpersonal interaction, 'Teamwork,' 'Problem solving,' 'Innovation,' 'Responsibility and discipline', and 'Information technology application.' The professional competencies are according to career clusters and manifest different career pathways. Regarding professional competency, occupations have been divided into 16 career clusters including 1. Agriculture, Food and Natural Resources, 2.Architecture and Construction, 3.Arts, A/V Technology and Communications, 4.Business, Management, and Administration, 5. Education and Training, 6.Finance, 7.Government and Public Administration, 8.Health Science, 9.Hospitality and Tourism, 10.Human Services, 11.Information Technology, 12.Law, Public Safety, and Security, 13.Manufacturing, 14.Marketing, Sales, and Service, 15.Science, Technology, Engineering, and Mathematics, and 16.Transportation, Distribution, and Logistics (States' Career Clusters Initiative, 2005). In the 'Career Interest Survey,' the system could produce Holland Codes automatically and count the students' degree of interest. Also, the 'Graduates Flow Survey' collects the data of alumni feedback.

Three types of users can log in to the system. The first one is the student, the second is the teacher and the third type is the manager. Using the system, every student can check his or her evaluation record. The teacher can check the students' results in his or her class in the system. About the manager of the UCAN system, he or she can detect all the students' records in the case university from the backstage platform called the UCAN report system. In the UCAN report system (Figure 2), the manager can link the data of common competencies, professional competencies, and career interest among students at campus and graduates in the vocational industries to carry out the competencybased assessment. In the backstage statistical analysis model, we linked two periods between learning 


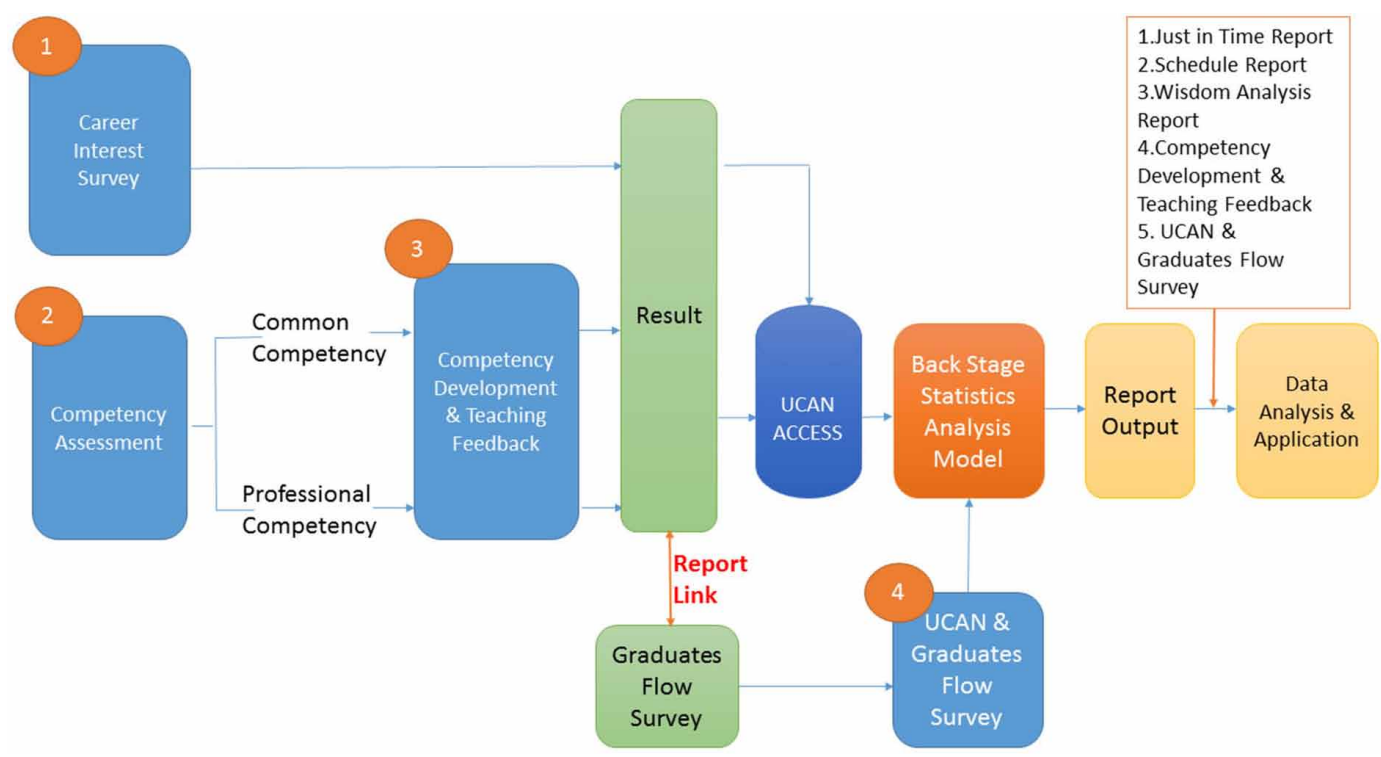

on campus and working in industries to check the difference. The UCAN report system is useful in detecting problems, trends in outcomes, and in improving competency distribution in curriculum maps from the real situation at the actual workplace.

\section{Curriculum Map}

A good curriculum planning with a bottom-up implementation can personalize the curriculum to meet learners' needs (Yuen et al, 2018). The curriculums are a complex mix of educational policies, course contents, learning outcomes, educational experiences, educational environment, students' personality, and career planning, (Harden, 2001). Curriculum maps are integrated with statements of educational objectives, learning activities, curriculum materials, assessment, learning outcomes. Also, in the higher education setting, curriculum maps provide real-time information to enhance collaboration and improve cooperative interaction among colleagues (Uchiyama \& Radin, 2009). A curriculum map guides university teachers to integrate teaching contents with occupational competencies. Moreover, the competency-based curriculum map becomes a useful tool for curriculum designers and coordinators (Al-Shakarchi et al, 2019; Perera et al., 2017; Sánchez Carracedo et al., 2018). The use of a curriculum map enables each department to regularly review and update their curriculum design according to vocational needs. Because of these valuable functions, many universities apply curriculum mapping not only to assure the teaching quality but also to attract potential students (Wang, 2015). According to Willett's (2008) empirical study of the implementation of curriculum mapping in Canada and the United Kingdom, many higher education institutions follow outcome-based (vocational skills and professional competencies) educational models. It has been demonstrated that curriculum mapping is data-driven and also competency-driven. In our study, we followed the curriculum map to detect the competency and set up a competency-based development plan to improve insufficient skills in different career clusters.

\section{Professional Competence of Information Technology}

In career clusters, the introduction of information technology will lead to the development of different professional competencies like network planning and construction management, information support 
and services, digital content and communication, and software development and programming. Studies have shown how the introduction of information technology competency have contributed to the service supply chain practices in the hospital industry (Jalilvand et al., 2019) and performance of a firm (Ndungu et al., 2017; Pett et al., 2010; Wei \& Wei, 2017). In the educational area, some researchers evaluated students' competence of information technology (IT) and recommended curricular changes (Avdeeva et al, 2017; Ni \& Chen, 2016; Nwosu et al., 2018). Also, information technology competencies have been applied in different industries such as IT, manufacturing, service in working areas for improvement of employees' knowledge or skills (Barbu \& Militaru, 2019; Liu, et al., 2016; Paramanandam, 2016; Spraakman et al., 2015). In our study, the alumni feedback was collected and analyzed to evaluate the curriculum design. It can offer evidence-based data to check the need for vocational training to students before their graduation.

\section{METHODS}

\section{Samples and Procedures}

In the present study, we linked data between the UCAN system and alumni survey of 'Vocational Satisfaction' from the office of students' affairs in the case university to find the deficiency in training and learning items in the campus. The alumni survey was carried out by the Office of Students' Affairs in the case university. The graduate flow survey of MOE, Taiwan was filled online for three months from June to September end in 2016 after one year of work. A cross report from the UCAN system was created among graduates at the end of 2016. All the alumni who graduated in 2015 were invited to answer the alumni survey by each college in the case university. The data from two surveys between UCAN and graduate flow was linked in the UCAN report system; finally, there were a total of 1,080 students who answered UCAN and alumni questionnaires in this study. The participants were from five colleges; Design (137), Management (491), Science and Engineering (128), Informatics (151), and Humanities and Social Sciences (173). The record of the UCAN was the updated score before graduation at school. Thus, we would be able to see their readiness for common and professional competencies after one-year of work experience. Regarding workplaces, there were seven clusters including private companies, government institutions, schools, non-profit companies, entrepreneurs, freelancers, and others.

\section{Measures and Variables}

All the questionnaires are closed questions. There are three parts in career clusters' interest survey including the activities that describe what students like to do (102 items), the personal qualities that describe them (54 items), and the topics or school subjects they like (38 items). The variables of common competencies in all five colleges were the same; however, professional competencies were different from career clusters. From the alumni survey, we could find different types of workplaces. In the questionnaire of common competencies, there were 52 items. In professional competency diagnosis, there were about 20 items in one career pathway according to different career clusters.

Regarding the assessment of professional and universal competency defined below, students were asked to use a 5-point 'Likert scale' to rate in the survey:

1. I can't finish it and learning it is difficult.

2. I can't finish it, but maybe I can learn by working hard.

3. I can't finish it, but I can learn it well by working hard.

4. I can finish it, and it will be better.

5. I can finish it and can do it correctly. 
Items in the alumni questionnaire on satisfaction and congruence were with a score of 5 (Strongly agree with 5 points, agree with 4 points, 3 points in general, do not agree with 2 points, strongly do not agree with 1 point) scores, including 'I am satisfied with the current job', and 'The current job fits well with the program learned at school'. Basic statistics analyses, ANOVA, and correlation were carried out in the results.

\section{RESULTS}

\section{Common Competencies Among the Five Colleges}

From ANOVA, we found that 'Interaction' ( $p$-value $=0.043<0.05$ ) and 'Innovation' ( $p$-value $=0.025<0.05$ ) of common competencies among the five colleges were significantly different. Regarding Interaction (Table 1), the highest score (Mean=4.19) was obtained by students in the College of Design, and the lowest was recorded in the College of Informatics (Mean=3.65).

Innovation score was the highest (Mean=3.99) in the College of Design, and the lowest in the College of Science and Engineering ( $\& \& E)(M e a n=3.40)$. Among the four departments in the College of S\&E, students in the department of construction engineering got the lowest scores.

\section{College Curriculum Maps}

Regarding 'Interaction,' students in the College of Informatics were significantly lower (Mean=3.65) compared to other colleges. The curriculum map of the Department of Information Management showed that a course on Human Resources Management (HRM) about interaction had been listed as one of the optional courses rather than required ones in the last semester of four academic years. Other curriculums had a bias towards system and programming.

Among the five colleges, Innovation had the lowest score (Mean=3.40) in the College of Science and Engineering. In the curriculum map of 2011, it was found that there was no Innovation course at all. Therefore, since 2013 the curriculum committee added a course on "Creativity" in the second semester in the Department of Construction Engineering. We assessed the records of universal competency in Innovation from UCAN in 2016 and found that 42 students answered the questionnaire, and the average score of Innovation enhanced to 4.03.

\section{Congruence and Satisfaction}

The congruence of Professional Practice in the college of Informatics was the lowest among all colleges (Table 2). Besides, the Satisfaction score is also the worst in the 'after one-year questionnaires' (Table 3).

From correlation analyses (Table 4), there are two findings as below:

1. Responsibility and discipline were significantly positive to Fit.

2. The fit was positive to Satisfaction.

Responsibility and discipline were significantly positive in Communication and expression, Interpersonal interaction, and Teamwork.

Higher the Learn-Practice Fit, higher was the 'Satisfaction' at workplaces. Therefore, competency training in 'Responsibility and discipline' was found to be very important before undergraduates enter the vocational world. Responsibility and discipline can be developed by improving 'Communication and expression', 'Interpersonal interaction', and 'Teamwork'. Thus, it can be inferred that "Internships" and "Projects" play a beneficial role in adapting to the workplace. 
Table 1. Common competency statistics among the five colleges

\begin{tabular}{|c|c|c|c|c|c|c|c|c|c|}
\hline \multicolumn{2}{|c|}{ College } & \multirow{2}{*}{$\begin{array}{l}\text { Communicate } \\
3.80\end{array}$} & \multirow{2}{*}{$\begin{array}{l}\text { Continuous } \\
\text { Learning }\end{array}$} & \multirow{2}{*}{$\begin{array}{l}\text { Interaction } \\
4.19\end{array}$} & \multirow{2}{*}{$\begin{array}{l}\text { Teamwork } \\
4.18\end{array}$} & \multirow{2}{*}{$\begin{array}{c}\begin{array}{c}\text { Problem- } \\
\text { Solving }\end{array} \\
3.91\end{array}$} & \multirow{2}{*}{$\begin{array}{l}\text { Innovation } \\
3.99\end{array}$} & \multirow{2}{*}{$\begin{array}{l}\text { Responsibility } \\
\text { and Discipline }\end{array}$} & \multirow{2}{*}{ 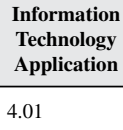 } \\
\hline & M & & & & & & & & \\
\hline \multirow[t]{2}{*}{ Design } & SD & 0.38 & 0.42 & 0.35 & 0.30 & 0.42 & 0.37 & 0.40 & 0.30 \\
\hline & $\mathrm{N}$ & 132 & 132 & 132 & 132 & 132 & 132 & 132 & 132 \\
\hline \multirow{3}{*}{ Management } & M & 3.61 & 3.63 & 3.98 & 3.96 & 3.58 & 3.56 & 4.07 & 3.87 \\
\hline & SD & 0.16 & 0.22 & 0.18 & 0.19 & 0.15 & 0.27 & 0.07 & 0.24 \\
\hline & $\mathrm{N}$ & 393 & 393 & 393 & 393 & 393 & 393 & 393 & 393 \\
\hline \multirow{3}{*}{$\begin{array}{l}\text { Science \& } \\
\text { Engineering }\end{array}$} & M & 3.44 & 3.60 & 3.76 & 3.95 & 3.73 & 3.40 & 4.06 & 3.93 \\
\hline & SD & 0.39 & 0.52 & 0.45 & 0.35 & 0.21 & 0.40 & 0.41 & 0.48 \\
\hline & $\mathrm{N}$ & 52 & 52 & 52 & 52 & 52 & 52 & 52 & 52 \\
\hline \multirow{3}{*}{ Informatics } & M & 3.35 & 3.56 & 3.65 & 3.79 & 3.53 & 3.45 & 3.85 & 3.73 \\
\hline & SD & 0.34 & 0.42 & 0.30 & 0.48 & 0.35 & 0.38 & 0.26 & 0.17 \\
\hline & $\mathrm{N}$ & 74 & 74 & 74 & 74 & 74 & 74 & 74 & 74 \\
\hline \multirow{3}{*}{$\begin{array}{l}\text { Humanities } \\
\text { and Social } \\
\text { Sciences }\end{array}$} & M & 3.60 & 3.52 & 3.90 & 3.98 & 3.63 & 3.43 & 4.07 & 3.97 \\
\hline & SD & 0.36 & 0.56 & 0.29 & 0.18 & 0.28 & 0.36 & 0.28 & 0.21 \\
\hline & $\mathrm{N}$ & 156 & 156 & 156 & 156 & 156 & 156 & 156 & 156 \\
\hline \multirow{3}{*}{ Total } & M & 3.56 & 3.67 & 3.90 & 3.97 & 3.67 & 3.57 & 4.05 & 3.90 \\
\hline & SD & 0.35 & 0.45 & 0.36 & 0.33 & 0.31 & 0.40 & 0.31 & 0.29 \\
\hline & $\mathrm{N}$ & 807 & 807 & 807 & 807 & 807 & 807 & 807 & 807 \\
\hline
\end{tabular}

Note: M=Mean, $S D=S$ tandard error, N=Number of participants

Table 2. Fit in Five Colleges

\begin{tabular}{|l|l|l|l|l|l|}
\hline \multicolumn{1}{|c|}{ College } & \multicolumn{1}{c|}{ Very Fit } & \multicolumn{1}{c|}{ Fit } & \multicolumn{1}{c|}{ Normal } & \multicolumn{1}{c|}{ Misfit } & \multicolumn{1}{c|}{ Very Misfit } \\
\hline Management & $10.10 \%$ & $41.09 \%$ & $36.64 \%$ & $8.84 \%$ & $5.33 \%$ \\
\hline $\begin{array}{l}\text { Science \& } \\
\text { Engineering }\end{array}$ & $13.33 \%$ & $30.37 \%$ & $35.56 \%$ & $12.59 \%$ & $8.15 \%$ \\
\hline Design & $12.39 \%$ & $41.03 \%$ & $31.62 \%$ & $9.83 \%$ & $5.13 \%$ \\
\hline $\begin{array}{l}\text { Humanities and } \\
\text { Social Sciences }\end{array}$ & $20.19 \%$ & $32.18 \%$ & $28.08 \%$ & $11.99 \%$ & $7.57 \%$ \\
\hline Informatics & $3.65 \%$ & $24.09 \%$ & $32.85 \%$ & $19.71 \%$ & $19.71 \%$ \\
\hline
\end{tabular}

\section{Career Clusters in the Department of Information Management}

The congruence of Professional Practice in the College of Informatics was the lowest (Mean=2.72) among the five colleges. Besides, the Satisfaction score was also lower (Mean=3.48). Following the career clusters, we evaluated the gaps in professional competencies in the Department of Information Management.

In Table 5, there are four career clusters in the professional competency of information technology including network planning and construction management, information support and services, digital content and communication, and Software development and programming. In all, there were 22 core competencies in the career of information technology. 
Table 3. Satisfaction in Five Colleges

\begin{tabular}{|l|l|l|l|l|l|}
\hline \multicolumn{1}{|c|}{ College } & \multicolumn{1}{c|}{ Very Fit } & \multicolumn{1}{c|}{ Fit } & \multicolumn{1}{c|}{ Normal } & \multicolumn{1}{c|}{ Misfit } & \multicolumn{1}{c|}{ Very Misfit } \\
\hline Management & $12.20 \%$ & $42.36 \%$ & $40.81 \%$ & $4.35 \%$ & $0.28 \%$ \\
\hline $\begin{array}{l}\text { Science \& } \\
\text { Engineering }\end{array}$ & $12.59 \%$ & $37.04 \%$ & $45.19 \%$ & $4.44 \%$ & $0.74 \%$ \\
\hline Design & $9.83 \%$ & $46.58 \%$ & $38.89 \%$ & $3.85 \%$ & $0.85 \%$ \\
\hline $\begin{array}{l}\text { Humanities and } \\
\text { Social Sciences }\end{array}$ & $9.78 \%$ & $40.69 \%$ & $44.79 \%$ & $4.10 \%$ & $0.63 \%$ \\
\hline Informatics & $9.49 \%$ & $34.31 \%$ & $51.82 \%$ & $3.65 \%$ & $0.73 \%$ \\
\hline
\end{tabular}

Table 4. The Correlation

\begin{tabular}{|c|c|c|c|c|c|c|c|c|c|c|c|}
\hline & & 1 & 2 & 3 & 4 & 5 & 6 & 7 & 8 & 9 & 10 \\
\hline \multirow{2}{*}{ 1. Communicate } & $\begin{array}{l}\text { Pearson } \\
\text { correlation }\end{array}$ & 1 & & & & & & & & & \\
\hline & Sig. & & & & & & & & & & \\
\hline \multirow{2}{*}{$\begin{array}{l}\text { 2. Continuous } \\
\text { Learning }\end{array}$} & $\begin{array}{l}\text { Pearson } \\
\text { correlation }\end{array}$ & .767 & 1 & & & & & & & & \\
\hline & Sig. & .130 & & & & & & & & & \\
\hline \multirow{2}{*}{ 3. Interaction } & $\begin{array}{l}\text { Pearson } \\
\text { correlation }\end{array}$ & $.992 * *$ & .807 & 1 & & & & & & & \\
\hline & Sig. & .001 & .099 & & & & & & & & \\
\hline \multirow[t]{2}{*}{ 4. Teamwork } & $\begin{array}{l}\text { Pearson } \\
\text { correlation }\end{array}$ & $.940^{*}$ & .834 & $.936^{*}$ & 1 & & & & & & \\
\hline & Sig. & .017 & .079 & .019 & & & & & & & \\
\hline \multirow{2}{*}{ 5. Problem Solving } & $\begin{array}{l}\text { Pearson } \\
\text { correlation }\end{array}$ & .707 & .863 & .714 & $.897 *$ & 1 & & & & & \\
\hline & Sig. & .181 & .059 & .176 & .039 & & & & & & \\
\hline \multirow{2}{*}{ 6. Innovation } & $\begin{array}{l}\text { Pearson } \\
\text { correlation }\end{array}$ & .827 & $.978 * *$ & .860 & .824 & .776 & 1 & & & & \\
\hline & Sig. & .084 & .004 & .062 & .086 & .123 & & & & & \\
\hline \multirow{2}{*}{$\begin{array}{l}\text { 7. Responsibility } \\
\text { and discipline }\end{array}$} & $\begin{array}{l}\text { Pearson } \\
\text { correlation }\end{array}$ & $.894^{*}$ & .668 & $.889 *$ & $.955^{*}$ & .807 & .649 & 1 & & & \\
\hline & Sig. & .041 & .218 & .044 & .011 & .099 & .236 & & & & \\
\hline \multirow{2}{*}{$\begin{array}{l}\text { 8. Information } \\
\text { technology } \\
\text { application }\end{array}$} & $\begin{array}{l}\text { Pearson } \\
\text { correlation }\end{array}$ & .790 & .519 & .748 & $.892 *$ & .790 & .487 & $.941^{*}$ & 1 & & \\
\hline & Sig. & .112 & .370 & .146 & .042 & .112 & .405 & .017 & & & \\
\hline \multirow{2}{*}{ 9. Satisfaction } & $\begin{array}{l}\text { Pearson } \\
\text { correlation }\end{array}$ & .809 & .563 & .847 & .778 & .538 & .575 & .874 & .678 & 1 & \\
\hline & Sig. & .097 & .323 & .070 & .122 & .350 & .310 & .053 & .209 & & \\
\hline \multirow{2}{*}{ 10. Fit } & $\begin{array}{l}\text { Pearson } \\
\text { correlation }\end{array}$ & .795 & .350 & .778 & .773 & .500 & .371 & $.913^{*}$ & .860 & $.890^{*}$ & 1 \\
\hline & Sig. & .108 & .564 & .121 & .125 & .391 & .538 & .031 & .062 & .043 & \\
\hline
\end{tabular}

Note: ${ }^{* *} . p<0.01 ;{ }^{*} . p<0.05 ;$ Sig.(2-tailed) 
Table 5. Professional Competency of Information Technology

\begin{tabular}{|c|c|}
\hline Career Cluster & Core Competency \\
\hline $\begin{array}{l}\text { 1. Network planning and construction } \\
\text { management }\end{array}$ & $\begin{array}{l}\text { 1.1 Perform network system implementation } \\
\text { 1.2 Perform network system planning } \\
\text { 1.3 Perform network maintenance and management } \\
\text { 1.4 Perform analysis of network requirements }\end{array}$ \\
\hline 2. Information support and services & $\begin{array}{l}\text { 2.1 Implement and support information technology-related services } \\
\text { and work } \\
\text { 2.2 Perform information system installation } \\
\text { 2.3 Executive Information System Update Service } \\
\text { 2.4 Write the records of maintenance, operation, and service } \\
\text { 2.5 Ensure the quality of information services }\end{array}$ \\
\hline 3. Digital content and communication & $\begin{array}{l}\text { 3.1 Carry out program design and project content verification } \\
\text { 3.2 Production of images, audio and video, programs and human- } \\
\text { machine interface solutions } \\
\text { 3.3 Display, trial, and correction of digital content dissemination } \\
\text { products } \\
\text { 3.4 Planning digital content and communication projects } \\
\text { 3.5 Identify and analyze target audience requirements }\end{array}$ \\
\hline 4. Software development and programming & $\begin{array}{l}\text { 1.1 System analysis based on the needs of the project } \\
\text { 1.2 System design based on the needs of the project } \\
\text { 1.3 Execution system import } \\
\text { 1.4 Provide product maintenance and customer support services to } \\
\text { maintain the proper operation of software and applications } \\
\text { 1.5 Test program to confirm compliance with quality requirements } \\
\text { 1.6 Develop and write programs } \\
\text { 1.7 Write technical documents and user manuals } \\
\text { 1.8 Confirm the development or programming requirements of the } \\
\text { software }\end{array}$ \\
\hline
\end{tabular}

Among the 22 core competencies of information technology, there were four items with Mean $<3$. In the Information support and services, it lacked core competency of Implementing and supporting information technology-related services and work, and core competency of Writing the records of maintenance, operation, and service. In the Software development and programming, it lacked core competency of Provision of product maintenance and customer support services for maintenance and normal operation of software and applications and core competency of Writing technical documents and user manuals. The training of system development and application was found to be satisfactory by alumni; however, the service and technical writing scored poorly in the evaluation.

\section{DISCUSSION}

\section{Innovation}

The new curriculum can facilitate 'Innovation' and help students in performing better in vocational areas. In 2007, the European Union called for further research on the skills and competencies required for incremental innovation on products, processes, and organizational and marketing methods. Worker' skills and innovation have been called the drivers of economic growth (Lloyd-Ellis \& Roberts, 2002), and college students have been identified as the major force for future innovations (Chen, 2013). In the learning process of higher education, students should be able to produce creative solutions to multiple tasks to develop their competence and innovativeness in changing circumstances (Hero et al, 2017; Lepistö \& Lindfors, 2015; McLellan \& Nicholl, 2011). Therefore, any kind of novel ideas, products, processes, services could be designed in the related curriculum map on campus. 


\section{Communication and Expression}

Communication has become the most demanded competence in the increasingly competence-driven world. Training curriculums on communication skills can help workers to cope with customer feedback (Dunbar, Brooks \& Kubicka-Miller, 2006, Mirchandani, 2012; Roberts, 2010). Besides, the competency of communication is positive to job performance (Jahwari et al., 2016; Khamkhaeng \& Rojniruttikul, 2019; Yu \& Ko; 2017). So the training of good communication and expression is necessary to be concentrated. From our findings, it is evident that 'Communication and expression,' 'Interpersonal interaction', and 'Teamwork' can help students to adapt to the workplace at a faster pace. Higher the Learn-Practice Fit, higher will be Satisfaction at the workplace. Also, a course related to internships and projects can help to improve communication and expression skills. In a nutshell, training of undergraduates on these aspects before graduation is imperative.

\section{Customer Support Service}

In our findings, the ability of customer support service was poor in the evaluation. The customer support service should not only rely on the technique (Schultze, 2003) but also focus on the customer relationships when designing and maintaining the product in IT industries (Roos, Löfgren \& Edvardsson, 2013). Systematic customer relationship management has a positive influence on service quality (Tseng, 2016). And good service quality has direct positive effects on customer loyalty (Makanyeza \& Chikazhe, 2017). From the curriculum map in the Department of Information Management, we found that concerning the service training in professional competencies, there were some management courses such as operational management, marketing management, and customer relationship management. Since the administration is highly related to service, therefore, a teacher needs to emphasize the core ability to improve their skill of service.

\section{Technical Writing}

The skill of records or document writing needs to be enhanced. For example, ISO-27001 certification requires certain documents to be filled; therefore, teachers need to train students to acquire these skills. While in the course of Technology English, the training can also be arranged to improve competitive capability in Information Technology writing in English. Cragg (2008) stated that important information system type resources include skills, knowledge, and technology. While knowledge learning is more at school, however, skill training is also necessary as concluded from the alumni feedback. Langley (2007) described that the production of technically sound user manuals could bring key messages across while keeping customers happy and reducing pressure on support staff. Schwartz (2012) demonstrated that technical writing ability makes organizations more efficient in creating content and in reducing the manual labor and costs involved in producing documents in several languages. Besides, some researchers paid attention to the training of technical writing ability in engineering students and confirmed its importance (Ibrahim et al., 2017; Nagao, 2018; Rashidi \& Mazdayasna, 2016; Ueasiriphan \& Tangkiengsirisin; 2019). Following the career clusters, we evaluated the insufficient professional competencies of technical manual writing in the Department of Information Management. Therefore, the addition of the service items of core ability in management courses, the skill of technical writing in TQM and ISO documentation, and improvement in Technology English are necessary attributes.

\section{IMPLICATION AND RECOMMENDATION}

In the finding of informatics results, the alumni replied that they lacked the training of interaction in the common competency, thus the lowest learn-practice fit leading to lower satisfaction at workplaces. Besides, they lacked professional competencies of service and writing. Therefore, the curriculum committee needs to modify the course credits in compulsory and elective curriculums in the first step. 
Secondly, internships and project training can enhance the understanding of real workplaces. Also, training is needed to be facilitated at earlier stages and not in the final year. The design of a more competency-based curriculum can let the students adapt the career easily and quickly.

Thirdly, facing different industries, soft skills are also necessary for informatics students. Through multiple intelligent planning and application, the students in the informatics department can learn interdisciplinary curriculum from other colleges such as management and design. After graduation, they can choose jobs flexibly or transfer to interesting careers easily.

Finally, the UCAN system plays an important role between alumni and undergraduates on the campus. Timely and quality feedback can shorten the gap between industries and schools. The system can avoid the predicament of real face-to-face, and improve the channel of communication in the training process. In further research, the graduate flow in different years can be traced and evaluated to check the outcome of curriculum improvement.

\section{CONCLUSION}

The competency-based diagnosis in the UCAN system was carried out to support multiple shreds of evidence in enriching the improvement of curriculum development. Through the diagnosis of career interest, common competencies, and professional competencies, we can understand the sufficiency and employability of different career pathways. From the alumni survey and feedback, we can explore the satisfaction and congruence after one year of graduation. Also, as an outcome of this study, the curriculum committee in the informatics college can change the weight of compulsory and elective curriculums, especially the insufficiency of career clusters in the curriculum map. In the UCAN report system, the results are beneficial to detect problems, trends in outcomes, and allow for higher adaption in their careers after graduation and joining the real workplace. Also, the feedback will be of immense help to teachers in improving their teaching strategies. 


\section{REFERENCES}

Al-Shakarchi, N., Obolensky, L., Walpole, S., Hemingway, H., \& Banerjee, A. (2019). Global health competencies in UK postgraduate medical training: A scoping review and curricular content analysis. BMJ Open, 9(8), 1-9. doi:10.1136/bmjopen-2018-027577 PMID:31446406

Avdeeva, S., Rudnev, M., Vasin, G., Tarasova, K., \& Panova, D. (2017). Assessing information and communication technology competence of students: Approaches, tools, validity, and reliability of results. Voprosy Obrazovaniya, 4(2017), 104-132. doi:10.17323/1814-9545-2017-4-104-132

Barbu, A., \& Militaru, G. (2019). Value co-creation between manufacturing companies and customers. The role of information technology competency. Procedia Manufacturing, 32, 1069-1076. doi:10.1016/j.promfg.2019.02.323

Boahin, P., Eggink, J., \& Hofman, A. (2014). Competency-based training in international perspective: Comparing the implementation processes towards the achievement of employability. Journal of Curriculum Studies, 46(6), 839-858. doi:10.1080/00220272.2013.812680

Bossers, A., Miller, L. T., Polatajko, H. J., \& Hartley, M. (2002). Competency based fieldwork evaluation for occupational therapists. Delmar.

Bossers, A., Miller, L. T., Polatajko, H. J., \& Hartley, M. (2007). Competency based fieldwork evaluation for occupational therapists CBFE-OT. Nelson Education.

Boury, T. T., Hineman, J. M., Klentzin, J. C., \& Semich, G. W. (2013). The use of online technology to facilitate pre-service teachers' engagement and cultural competency development during an international field placement: Reflections from Austria. International Journal of Information and Communication Technology Education, 9(3), 65-79. doi:10.4018/jicte.2013070105

Chen, A., Li, L., Li, X., Zhang, J., \& Dong, L. (2013). Study on innovation capability of college students based on extenics and theory of creativity. Procedia Computer Science, 17, 1194-1201. doi:10.1016/j.procs.2013.05.152

Commission on Accreditation of Healthcare Management Education. (2015). Criteria for accreditation. Retrieved from https://cahme.org/Resources/Fall2013_CriteriaForAccreditation.pdf

Cragg, P. (2008). Identifying key information systems competencies in small firms. Total Quality Management \& Business Excellence, 19(1-2), 29-35. doi:10.1080/14783360701601926

Davies, S., Reitmaier, A., Smith, L. R., \& Mangan-Danckwart, D. (2013). Capturing intergenerativity: The use of student reflective journals to identify learning within an undergraduate course in gerontological nursing. The Journal of Nursing Education, 52(3), 139-149. doi:10.3928/01484834-20120213-01 PMID:23402281

De St Jorre, T. J., \& Oliver, B. (2018). Want students to engage? Contextualise graduate learning outcomes and assess for employability. Higher Education Research \& Development, 37(1), 44-57. doi:10.1080/07294360.2 017.1339183

Dunbar, N. E., Brooks, C. F., \& Kubicka-Miller, T. (2006). Oral communication skills in higher education: Using a performance-based evaluation rubric to assess communication skills. Innovative Higher Education, 31(2), 115-128. doi:10.1007/s10755-006-9012-x

Elliott, A. M. (2017). Professional values competency evaluation for students enrolled in a conceptbased curriculum. The Journal of Nursing Education, 56(1), 12-21. doi:10.3928/01484834-20161219-04 PMID:28118470

Elstad, E., Lejonberg, E., \& Christophersen, K.-A. (2015). Teaching evaluation as a contested practice: Teacher resistance to teaching evaluation schemes in Norway. Education Inquiry, 6(4), 375-399. doi:10.3402/edui. v6.27850

Gunawardena, E. (2014). An analysis of the competency-based secondary mathematics curriculum in Sri Lanka. Educational Research for Policy and Practice, 13(1), 45-63. doi:10.1007/s10671-013-9145-5

Harden, R. M. (2001). AMEE Guide No. 21: Curriculum mapping: a tool for transparent and authentic teaching and learning. Medical Teacher, 23(12), 123-137. doi:10.1080/01421590120036547 PMID:11371288 
Harshman, J., \& Yezierski, E. (2017). Assessment data-driven inquiry: A review of how to use assessment results to inform chemistry teaching. Science Educator, 25(2), 97-107.

Hero1, L.M., Lindfors, E., \& Taatila, V. (2017). Individual innovation competence: a systematic review and future research agenda. International Journal of Higher Education, 6(5), 103-121.

Hubbell, E. L. (2007). Technology in the early childhood classroom. Learning Connections. Retrieved June 30, 2009, Retrieved from www.mcrel.org/pdf/educationtechnology/9713IR_TechEarly Childhood.pdf

Ibrahim, S., Yunus, M. A. M., \& Khairi, M. T. M. (2017). Teaching academic writing for engineering students: Challenges and recommendations. International Journal of Education. Psychology and Counseling, 2(5), 160-169.

Iezzi, D. (2005). A method to measure the quality on teaching evaluation of the university system: The Italian case. Social Indicators Research, 73(3), 459-477.

Irvine, F. E., Roberts, G. W., Tranter, S., Williams, L., \& Jones, P. (2008). Using the critical incident technique to explore student nurses' perceptions of language awareness. Nurse Education Today, 28(1), 39-47. doi:10.1016/j. nedt.2007.02.010 PMID:17408813

Jalilvand, M., Khodadadi, M. \& Sharifi, M. (2019). Information technology competency and knowledge management in the hospitality industry service supply chain. Tourism Review of AIEST - International Association of Scientific Experts in Tourism, 872-884.

Jahwari, A., Sulaiman, D., Ercan, S. T., \& Volkan, A. (2016). Evaluating communication competency of tour guides using a modified importance-performance analysis (MIPA). International Journal of Contemporary Hospitality Management, 28(1), 195-218. doi:10.1108/IJCHM-02-2014-0064

Johari, M. H., Hamid, R., \& Baharom, S. (2016). Students' feedback for continuous quality improvement of materials technology course outcomes via teaching \& supervision evaluation system. Journal of Engineering Science and Technology, 11, 88-101.

Keengwe, J., \& Onchwari, G. (2009). Technology and early childhood education: A technology integration professional development model for practicing teachers. Early Childhood Education Journal, 37(13), 209-218. doi:10.1007/s10643-009-0341-0

Khamkhaeng, A., \& Rojniruttikul, N. (2019). Factors affecting communication of competency of operative employees: A case of plastic parts manufacturer. AU-GSB E-Journal, 12(1), 39-43.

Kumm, S., \& Laverentz, D. M. (2017). Concept-based curriculum evaluation: 5-year process. Journal of Teaching and Learning in Nursing, 12(4), 242-245. doi:10.1016/j.teln.2017.06.004

Langley, N. (2007). Technical writing provides career path with creativity. Computer Weekly, 60.

Lepistö, J., \& Lindfors, E. (2015). From gender-segregated subjects to multi-material craft: Craft student teachers' views on the future of the craft subject. Formakademisk, 8(3), 1-20. doi:10.7577/formakademisk.1313

Liu, H., Wei, S., Ke, W., Wei, K., \& Hua, Z. (2016). The configuration between supply chain integration and information technology competency: A resource orchestration perspective. Journal of Operations Management, 44(1), 13-29. doi:10.1016/j.jom.2016.03.009

Liu, X., Yu, Y., Zhang, J., Wei, S., \& Ding, L. (2016). On the effects, problems, and countermeasures of undergraduate teaching evaluation in higher education. Chinese Education \& Society, 49(1-2), 20-38. doi:10. $1080 / 10611932.2016 .1192383$

Lloyd-Ellis, H., \& Roberts, J. (2002). Twin engines of growth. Journal of Economic Growth, 2(2), 87-115. doi:10.1023/A:1015633528122

Lüer, S., \& Aebi, C. (2017). Assessment of residency program outcomes via alumni surveys. Advances in Medical Education and Practice, 8, 307-315. doi:10.2147/AMEP.S131043 PMID:28490914

Mah, D. K., \& Ifenthaler, D. (2017). Academic staff perspectives on first-year students' academic competencies. Journal of Applied Research in Higher Education, 9(4), 630-640. doi:10.1108/JARHE-03-2017-0023 
Makanyeza, C., \& Chikazhe, L. (2017). Mediators of the relationship between service quality and customer loyalty Evidence from the banking sector in Zimbabwe. International Journal of Bank Marketing, 35(3), 540-556. doi:10.1108/IJBM-11-2016-0164

McCall, M. W., \& Flyers, J. H. (1998). Developing the next generation of leaders. Boston: Harvard Business School Press; Career Planning Competency Model developed by Bowling Green State University. Retrieved from www.bgsu.edu

McLellan, R., \& Nicholl, B. (2011). If I was going to design a chair, the last thing I would look at is a chair. Product analysis and the causes of fixation in students' design work 11-16 years. International Journal of Technology and Design Education, 21(1), 71-92. doi:10.1007/s10798-009-9107-7

Miller, L., Bossers, A., Polatajko, H. J., \& Hartley, M. (2001). Competency based fieldwork evaluation for health sciences students. Occupational Therapy International, 8, 244-262. doi:10.1002/oti.149

Mirchandani, K. (2012). Learning racial hierarchies: Communication skills training in transnational customer service work. Journal of Workplace Learning, 24(5), 338-350. doi:10.1108/13665621211239877

Montoya, M. S. R. (2013). Challenges and perspectives for the open education movement in the distance education environment: A diagnostic study in a SINED project. International Journal of Educational Technology in Higher Education, 10(2), 414-430.

Nagao, A. (2018). A genre-based approach to writing instruction in EFL classroom contexts. Canadian Center of Science and Education: English Language Teaching, 11(5), 130. doi:10.5539/elt.v11n5p130

Ndungu, S., Wanjau, K., Gichira, R., \& Mwangi, W. (2017). Moderating role of entrepreneurial orientation on the relationship between information technology competence and firm performance in Kenya. International Journal of Professional Business Review, 2(2), 1-22. doi:10.26668/businessreview/2017.v2i2.59

Ni, A. Y., \& Chen, Y. C. (2016). A conceptual model of information technology competence for public managers: Designing relevant MPA curricula for effective public service. Journal of Public Affairs Education, 22(2), 193-212. doi:10.1080/15236803.2016.12002241

Nwosu, J. C., John, H. C., Izang, A. A., \& Akorede, O. J. (2018). Assessment of information and communication technology (ICT) competence and literacy skills among undergraduates as a determinant factor of academic achievement. Educational Research Review, 13(15), 582-589. doi:10.5897/ERR2018.3539

Onwuegbuzie, A. J., Witcher, A. E., Collins, K. M. T., Filer, J. D., Wiedmaier, C. D., \& Moore, C. W. (2007). Students' perceptions of characteristics of effective college teachers: A validity study of a teaching evaluation form using a mixed-methods analysis. American Educational Research Journal, 44(1), 113-160. doi:10.3102/0002831206298169

Paramanandam, P. (2016). Perceived self-competence as a predictor of job satisfaction among the employees of information technology industry. International Journal on Global Business Management \& Research, 5(2), 45-53.

Perera, S., Babatunde, S. O., Zhou, L., Pearson, J., \& Ekundayo, D. (2017). Competency mapping framework for regulating professionally oriented degree programmes in higher education. Studies in Higher Education, 42(12), 2316-2342. doi:10.1080/03075079.2016.1143926

Pett, T. L., Wolff, J. A., \& Perry, J. T. (2010). Information technology competency in SMEs: An examination in the context of firm performance. International Journal of Information Technology and Management, 9(4), 404-422. doi:10.1504/IJITM.2010.035462

Rashidi, N., \& Mazdayasna, G. (2016). Impact of genre-based instruction on development of students' letter writing skills: The case of students of textile engineering. Journal of Research in Applied Linguistics, 7(2), 55-72.

Ratri, D. P., Dewi, D. N., \& Hapsari, Y. (2019). A study of alumni feedback on pedagogical curriculum evaluation. Erudio Journal of Educational Innovation, 6(1), 48-60. doi:10.18551/erudio.6-1.6

Rizalyn,J. M., \& Shuichi, N. (2003). Makabayan curriculum for secondary schools in the Philippines: The development of citizenship. Educational Research for Policy and Practice, 2(1), 13-26. doi:10.1023/A:1024459602954

Roberts, C. (2010). Language socialization in the workplace. Annual Review of Applied Linguistics, 30, 211-227. doi:10.1017/S0267190510000127 
Roos, I., Löfgren, M., \& Edvardsson, B. (2013). Customer-support service from a relationship perspective: Best practice for telecom. Management Research and Practice, 5(2), 5-21.

Sánchez Carracedo, F., Soler, A., Martín, C., López, D., Ageno, A., Cabré, J., Garcia, J., Aranda, J., \& Gibert, K. (2018). Competency maps: An effective model to integrate professional competencies across a STEM curriculum. Journal of Science Education and Technology, 27(5), 448-468. doi:10.1007/s10956-018-9735-3

Schultze, U. (2003). Complementing self-serve technology with service relationships: The customer perspective. e-Service Journal, 3(1), 7-31.

Schwartz, H. (2012). Structured content and why it matters for global companies. Information Today, 29(4), 11.

Spraakman, G., O’Grady, W., Askarany, D., \& Akroyd, C. (2015). Employers' Perceptions of Information Technology Competency Requirements for Management Accounting Graduates. Accounting Education, 24(5), 403-422. doi:10.1080/09639284.2015.1089177

States' Career Clusters Initiative. (2005). Guidance division survey. Oklahoma Department of Career and Technology Education. Retrieved from https://www-cchs.ccsd.k12.wy.us/info/academy/assets/16clusters.pdf

Steel, S. (2018). Revisioning philosophy of education instruction in competency-based B. Ed. programs. Interchange, 49(4), 417-431. doi:10.1007/s10780-018-9340-7

Tseng, S. M. (2016). Knowledge management capability, customer relationship management, and service quality. Journal of Enterprise Information Management, 29(2), 202-221. doi:10.1108/JEIM-04-2014-0042

Uchiyama, K. P., \& Radin, J. L. (2009). Curriculum mapping in higher education: A vehicle for collaboration. Innovative Higher Education, 33(4), 271-280. doi:10.1007/s10755-008-9078-8

Ueasiriphan, T., \& Tangkiengsirisin, S. (2019). The Effects of Genre-Based Teaching on Enhancement of Thai Engineers' Technical Writing Ability. International Journal of Instruction, 12(2), 723-738. doi:10.29333/ iji.2019.12246a

Yu, S., \& Ko, Y. (2017). Communication competency as a mediator in the self-leadership to job performance relationship. Collegian (Royal College of Nursing, Australia), 24(5), 421-425. doi:10.1016/j.colegn.2016.09.002

Wang, C. L. (2015). Mapping or tracing? Rethinking curriculum mapping in higher education. Studies in Higher Education, 40(9), 1550-1559. doi:10.1080/03075079.2014.899343

Wei, S., \& Wei, K. K. (2017). The contingency effect of relational competency on the relationship between information technology competency and firm performance. Data and Information Management, 1(1), 3-16. doi:10.1515/dim-2017-0003

Wesselink, R., Dekker-Groen, A. M., Biemans, H. J. A., \& Mulder, M. (2010). Using an instrument to analyze competence-based study programmes: Experiences of teachers in Dutch vocational education and training. Journal of Curriculum Studies, 42(6), 813-829. doi:10.1080/00220271003759249

Willett, T. G. (2008). Current status of curriculum mapping in Canada and the UK. Medical Education, 42(8), 786-793. doi:10.1111/j.1365-2923.2008.03093.x PMID:18564300

Xiong, Q., \& Niu, X. (2018). Liberal arts core curriculum quality assurance based on teaching evaluation by students: A case study of Fudan University. Chinese Education \& Society: Teaching Reform in Chinese Undergraduate Education, 51(4), 260-271. doi:10.1080/10611932.2018.1481647

$\mathrm{Xu}, \mathrm{Y}$. (2012). Developing a comprehensive teaching evaluation system for foundation courses with enhanced validity and reliability. Educational Technology Research and Development, 60(5), 821-837. doi:10.1007/ s11423-012-9240-y

Yuen, S., Boulton, H., \& Byrom, T. (2018). School-based curriculum development as reflective practice: A case study in Hong Kong. Curriculum Perspectives, 38(1), 15-25. doi:10.1007/s41297-017-0032-8 
Dinesh Chandra Agrawal is working as a professor at the Chaoyang University of Technology (CYUT), Taiwan, and has more than 38 years of research experience in Plant Biotechnology of diverse species, including medicinal plants. He obtained his Ph.D. degree in 1982 from the HNB University of Garhwal (Central University), India. Dr. Agrawal has more than 180 publications to his credit, including five books (3 by Springer Nature). He is the recipient of several prestigious awards and fellowships, including Alexander von Humboldt, Germany, and has worked in the USA, Germany, and the UK. Currently, he is serving as Associate Editor-in-Chief of International Journal of Applied Science and Engineering (Scopus).

Hsing-Yu Hou is an assistant professor in the College of Information and Distribution Science, National Taichung University of Science and Technology, Taiwan. In 2009, she received her Ph.D. from the college of management, National Yunlin University of Science and Technology, Taiwan. She was a lecturer and assistant professor at the Transworld University of Science and Technology during 2000 and 2014. In 2012, she was a visiting scholar at Singapore Management University. She has done training in statistical analyses and data mining. Her research interests include e-learning, ergonomics, management information systems, and education programs.

Tao-Ming Cheng currently president of the Chaoyang University of Technology works as a professor in the Department of Construction Engineering. He received his Ph.D. degree in construction engineering and management from Purdue University, USA. His research interests include construction ergonomics, construction operations modeling, and higher education management. Dr. Cheng has published more than 100 journal and conference papers in the past decade. 